\title{
Ultrafiltration of Aqueous Solutions of Food Dye Using Polymeric Membranes Prepared with Surfactants
}

\author{
GEORGE ALEXANDRU POPA ${ }^{1}$, DANIELA FLORENTINA ENACHE (POPA) ${ }^{1}$, SZIDONIA KATALIN TANCZO ${ }^{2 *}$, ADRIAN CIOCANEA ${ }^{3}$ \\ 'University Politehnica of Bucharest, Department of Analytical Chemistry and Environmental Engineering, 1-3 Gh. Polizu Str., \\ 011061, Bucharest, Romania \\ 2Sapientia University, Libertatii Str, Miercurea Ciuc, 500104, Miercurea Ciuc, Romania \\ 3Politehnica University of Bucharest, Power Engineering Faculty-Hydraulics, Hydraulic Machinery and Environmental Engineering \\ Department, 313 Splaiul Independentei, 060042, Bucharest, Romania
}

\begin{abstract}
The objective of the study is the low-pressure membrane process for treating aqueous solutions containing synthetic food dye (E104 - quinoline yellow). Dye concentration used was $10 \%$ (equivalent to $100 \mathrm{~g} / \mathrm{m}^{3}$ ). The pressures used in the ultrafiltration process were 0.1, 0.2 and 0.3 MPa. Experiments were performed in dead - end instalations in which the effectiveness of the polysulfone - alkylbenzyldimethylammonium chloride (PSU-ABDMA) and polysulfone - N-dodecylpyridinium chloride (PSU - NDPCI) were tested. The efficiency of these membranes has been proved by calculating the permeate flow and the retention. Analyzing the experimental data, it was found that for the polysulfone-alkylbenzyldimethylammonium chloride composite membrane the degree of retention is completely different, with high values being obtained for low pressures and low values for high pressures used.
\end{abstract}

Keywords: composite membranes, ultrafiltration, surfactants, dye retention

The beginning of the millennium places the planet on a degrading stage due to the depletion of resources and the obvious destruction of the environment. This is predictable given that society is in continuous development from both a technical and economical point of view [1].

For most human services and activities, water is an important part of this puzzle because it depends on its availability and use. It also does not focus only on the quantity but also on the quality of the water as well as its source of origin [2].

Asymmetric membranes have led to an extraordinary development of membrane separation processes [3]. Membrane technologies interact with the field of surfactants in membrane conditioning and washing operations [4].

The study on the influence of surfactants in the filtering process using polymeric membranes has highlighted a series of exceptional phenomena with the help of which new methods of use has been found in the field like science and technology.

Baromembrane processes such as microfiltration, ultrafiltration, nanofiltration and reverse osmosis take place due to the pressure difference. These processes are among the top industrial applications. Thus the reverse osmosis process is similar to dehydration by hyperfiltration, ultrafiltration resembles the methods of concentration, purification and fractionation of molecules or colloids, and microfiltration is recognized for the separation of suspensions. So membrane processes can be a viable alternative to other separation processes [5-8].

The production of membranes can be influenced by the addition of small amounts of surfactants. The membrane process can also be controlled by the use of surfactants [6-11].

Surface active agents, also known as surfactants, are chemical substances which in solution concentrate to the surface and cause solubilization of low affinity substances with respect to each other. The accumulation at the separation surface of the surfactants makes them capable of substantial changes, even at low concentrations, of the superficial properties of the liquids in which they are dissolved.

Surfactants have an asymmetric molecular structure consisting of two parts with opposite fundamental features: a non-polar or weakly polar (hydrocarbon) partand a strong polar (ionizable or non-ionizable) moiety. The nonpolar part has the property of being hydrophobic and in strong polar liquids, but it is lipophilic in non-polar liquids. The polar side, on the contrary, is hydrophilic. Because of the various affinities they pose for the different phases, such molecules are called amphiphiles [11-13].

Currently, the improvement of the membrane techniques culminated in their passage into the applicability of extremely demanding areas such as:

- food industry (sterilization of juices, beer and wine, preparation of dairy products, sterile packaging of fruits and vegetables);

- electronics and electrotechnics (obtaining ultrapure water, preparation of electronic reagents, recovery of solutions containing rare compounds);

- biotechnologies (sterilization of culture media, separation of biomass, concentration and fractionation of proteins and enzymes);

- health (artificial kidney, pancreas and artificial lung, tissue replacements);

- environmental quality protection and monitoring (membrane sensors, recovery techniques, treatment and purification processes without chemical reagents, automated analytical means) [12].

Polymeric membranes are the largest category of filter materials marketed and applied at laboratory and industrial level, from microfiltration to reverse osmosis [12-15].

Composite membranes are currently an optimal solution for enhancing the performance of membrane materials used in various processes in terms of permeability and selectivity [16-24].

This paper presents the experimental results obtained by using composite membranes polysulfone alkylbenzyldimethylammonium chloride (PSU-ABDMA) 
and polysulfone-N-dodecylpyridinium chloride (PSU NDPCl).

\section{Experimental part \\ Materials and methods \\ Membranes}

This study used non commercial membranes. The ultafiltration membranes developed were polysulfone alkylbenzyldimethylammonium chloride (PSU-ABDMA) and polysulfone-N-dodecylpyridinium chloride (PSU NDPCl) [16-20].

For PSU - ABDMA, the poysulfone used was procurred from BASF (Ultrasonic S3010). As a solvent N-methyl pyrrolidone (Merck) was used and as a non-solvent a mix of isopropanol (Fluka) and deionized water (Fluka). The cation used was alkylbenzyldimethylammonium chloride (Merck). The polymer was purified by re-precipitation from chloroform and dried in vacuo at $60^{\circ} \mathrm{C}$. Into a glass stoppered Erlenmeyer beaker, the polymer was dissolved in the solvent using magnetic stirring until the desired concentration ( $12 \%$ polysulfone mixed in $\mathrm{N}$-methyl pyrrolidone - NMP) was reached. Using the dry and reprecipitated polymer, the solution is obtained within 4 hours. Before use, air is removed from the solution in a vacuum desiccator for $30 \mathrm{~min}$. A small amount of surfactant (the calculated concentration of $10^{-5} \mathrm{M}$ ) was added to a cylinder in $4 \mathrm{~mL}$ of N-methyl pyrrolidone - NMP. Thereafter, the surfactant solution was mixed with $20 \mathrm{~mL}$ polysulfone solution and vigorously stirred to disperse the surfactant throughout the volume of the polymer solution. The polymeric film deposited on the glass is immersed in the coagulation bath and the membrane is formed by precipitation of the polymer [21-24].

For polysulfone-N-dodecylpyridinium chloride (PSU NDPCI), the polisulfone used was procurred from BASF (Ultrasonic S3010). As a solvent N-methyl pyrrolidone (Merck) was used, and as a non-solvent a mix of isopropanol (Fluka) and deionized water (Fluka). The cation used was $\mathrm{N}$-dodecylpyridinium chloride. The polymer was purified by re-precipitation from chloroform and dried in vacuo at $60^{\circ} \mathrm{C}$. Into a glass stoppered Erlenmeyer beaker, the polymer was dissolved in the solvent using magnetic stirring until the desired concentration ( $12 \%$ polysulfone mixed in Nmethyl pyrrolidone - NMP) was reached. Using the dry and re-precipitated polymer, the solution is obtained within 4 hours. Before use, air is removed from the solution in a vacuum desiccator for $30 \mathrm{~min}$. A small amount of surfactant (the calculated concentration of $10^{-5} \mathrm{M}$ ) was added to a cylinder in $4 \mathrm{~mL}$ of $\mathrm{N}$-methyl pyrrolidone - NMP. Thereafter, the surfactant solution was mixed with $20 \mathrm{~mL}$ polysulfone solution and vigorously stirred to disperse the surfactant throughout the volume of the polymer solution. The polymeric film deposited on the glass is immersed in the coagulation bath and the membrane is formed by precipitation of the polymer [16-20].

\section{Experimental solutions}

The properties of the ultrafiltration membranes regarding transport and separation were determined on solutions containg E104 quinoline yellow synthetic dye. The molecular formula of $\mathrm{E} 104$ is: $\mathrm{C}_{18} \mathrm{H}_{13} \mathrm{NO}_{5 / 8 / 11} \mathrm{~S}_{1 / 2 / 3} \mathrm{Na}_{1 / 2 / 3}$ and the molecular weight amounts to $477.38 \mathrm{~g} / \mathrm{mol}$. It is used as a synthetic colouring agent in food and drink products, as well as in cosmetics.

\section{Ultrafiltration process}

The ultrafiltation process in the presence of surfactants was investigated in a pilot laboratory set - up (scheme I).
The membrane being tested had a diameter of $36 \mathrm{~mm}$. The pressures used in the ultrafiltration process were 0.1, 0.2 and $0.3 \mathrm{MPa}$. Permeate volume fluxes and retention coefficients were determined on stady flow conditions. Permeate volume flow was calculated as shown bellow:

$$
J=\frac{V}{t \cdot A}\left(m^{3} / m^{2} d a y\right),
$$

where: $V$ is the permeate volume $\left(\mathrm{m}^{3}\right)$, $t$ stands for the time (day), and $A$ represents the effective membrane surface area $\left(\mathrm{m}^{2}\right)$.

Dye retention coefficient $(R)$ was determined as

$$
R=\frac{C_{k}-C_{p}}{C_{k}} \cdot 100(\%)
$$

where $C k$ and $C p$ denote the dye concentration $\left(\mathrm{g} / \mathrm{m}^{3}\right)$ in retentate and permeate, respectively [25].

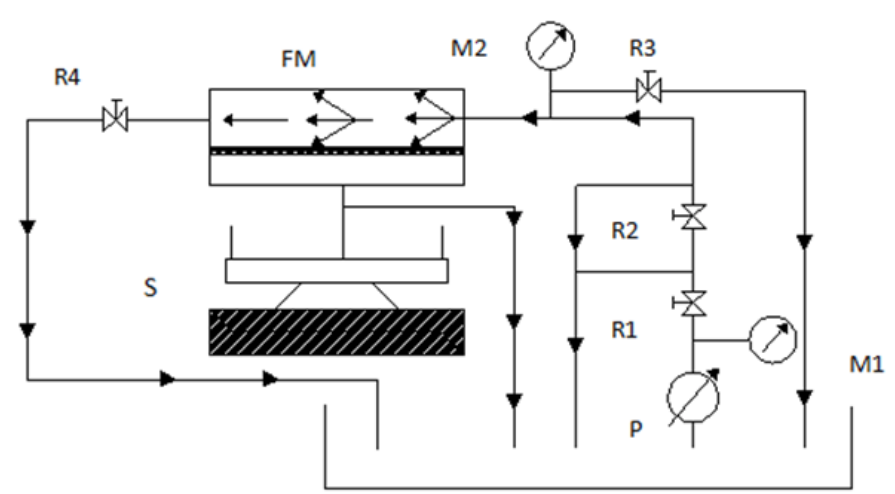

Scheme I. Pilot set-up: P -centrifugal pump, FM - filtration module, $\mathrm{S}$-digital scale, $\mathrm{R}$ - valve, $\mathrm{M}$ - manometer

To obtain a wider range of flow a centrifugal pump was used $(Q=40 \mathrm{l} / \mathrm{min})$, driven by a variable speed $(n=$ 287rpm). A digital laboratory balance, Mettler Toledo model, was used for weighing. The substrate surfaces used for the membranes will be molecular sieves, made of stainless steel. For this, AISI304MESH94 mesh sieve $110 \mu$ $(0.11 \mathrm{~mm})$ mesh opening $150 \mu(0.15 \mathrm{~mm})$ was used. This is mainly used in the pharmaceutical industry. To track the flow parameters through the membrane, equipment has been developed to highlight these aspects.

\section{Results and discussions}

Experiments were carried out to test the effectiveness of polysulfone-alkylbenzyl dimethyl ammonium chloride (PSU-ABDMA) and polysulfone - $\mathrm{N}$-dodecylpyridinium chloride (PSU - NDPCI). The efficiency of these membranes has been demonstrated by the calculation of permeate flow and retention coefficient.

The hydrodynamic characteristics obtained at three different pressures for the polysulfone - alkylbenzyldimethylammonium chloride (PSU - ABDMA) membranes were presented in figures 1-6.

Working conditions: Initial solution: $\mathrm{C}_{18} \mathrm{H}_{13} \mathrm{NO}_{5 / 8112} \mathrm{~S}_{1 / 23} \mathrm{Na}_{1 /}$ 10\% (equivalent to $100 \mathrm{~g} / \mathrm{m}^{3}$ ) - E104; Process duration: $30 \mathrm{~min}$; Spectrophotometric measurements at the wavelength of $575 \mathrm{~nm}$; Initial temperature: $19.2^{\circ} \mathrm{C}$; Final temperature: $23.4^{\circ} \mathrm{C}$; Pressure: $0.1 \mathrm{MPa}$; Operation of the installation: dead-end (figs. 1 and 2).

The membrane exhibiting in its structure the surfactant has a better flow for this operating pressure, ranging from 0.5260 to $1.3929 \mathrm{~m}^{3} / \mathrm{m}^{2}$ day.

Working conditions: Initial solution: $\mathrm{C}_{18} \mathrm{H}_{13} \mathrm{NO}_{5 / 8 / 11} \mathrm{~S}_{1 / 2 / 3}$ $\mathrm{Na}_{1 / 2 / 3}, 10 \%$ (equivalent to $100 \mathrm{~g} / \mathrm{m}^{3}$ ) - E104; Process duration: 30 min; Spectrophotometric measurements at the wavelength of $575 \mathrm{~nm}$; Initial temperature: $20.7^{\circ} \mathrm{C}$; Final 


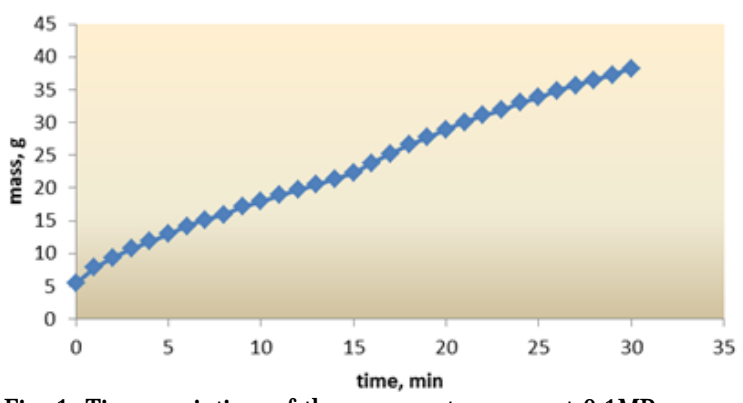

Fig. 1. Time variation of the permeate mass at $0.1 \mathrm{MPa}$ pressure for the polysulfone - alkylbenzyl dimethylammonium chloride

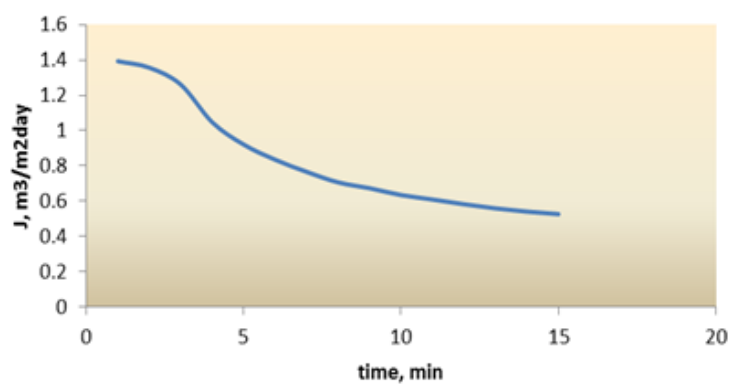

Fig. 2. Flow variation at $0.1 \mathrm{Mpa}$ for the polysulfone alkylbenzyldimethylammonium chloride

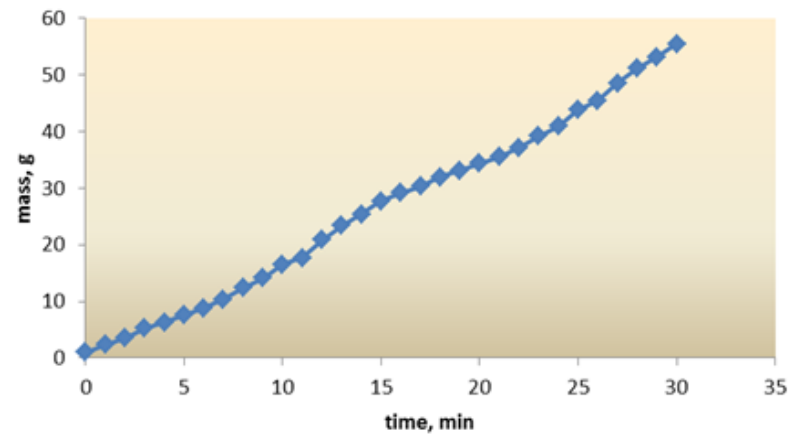

Fig. 3. Time variation of the permeate mass at $0.2 \mathrm{MPa}$ pressure for the polysulfone - alkylbenzyl dimethylammonium chloride

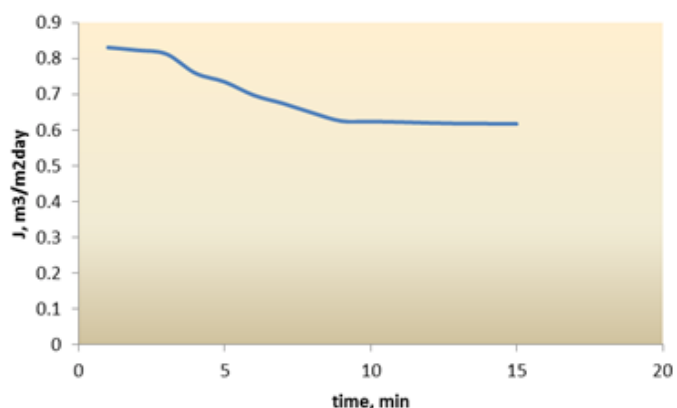

Fig. 4. Flow variation at $0.2 \mathrm{MPa}$ for the polysulfone alkylbenzyldimethylammonium chloride

temperature: $23.1^{\circ} \mathrm{C}$; Pressure: $\quad 0.2 \mathrm{MPa}$; Operation of the installation: dead-end (figs. 3 and 4).

For the same solution analyzed, at a pressure of 2 bar, the flow value is between 0.6171 and $0.8307 \mathrm{~m}^{3} / \mathrm{m}^{2}$ day, considerably lower values than those obtained under the same conditions at a pressure of 1 bar. Although the recorded values were lower than for the $0.1 \mathrm{MPa}$ pressure, the trend was constant and maintained.

Working conditions: Initial solution: $\mathrm{C}_{18} \mathrm{H}_{13} \mathrm{NO}_{5 / 811} \mathrm{~S}_{1 / 23} \mathrm{Na}_{1}$

$10 \%$ (equivalent to $100 \mathrm{~g} / \mathrm{m}^{3}$ ) - E104; Process duration: $30 \mathrm{~min}$; Spectrophotometric measurements at the wavelength of $575 \mathrm{~nm}$; Initial temperature: $19.8^{\circ} \mathrm{C}$; Final temperature: $22.3^{\circ} \mathrm{C}$; Pressure: $0.3 \mathrm{MPa}$; Operation of the installation: dead-end (figs. 5 and 6 ).

The flow value ranges from 0.4817 to $0.6725 \mathrm{~m}^{3} / \mathrm{m}^{2}$ day, maintaining a downward trend this time. Flow values for

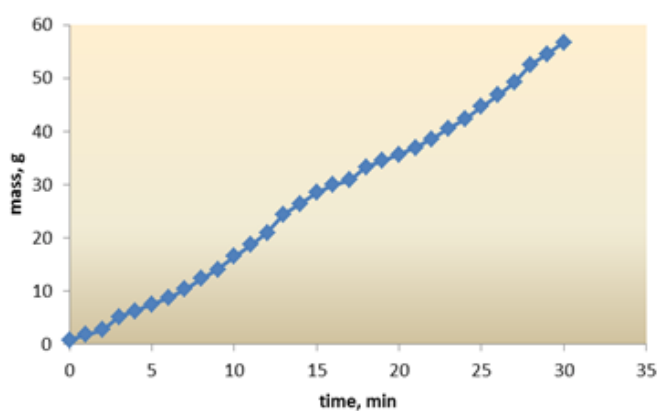

Fig. 5. Time variation of the permeate mass at $0.3 \mathrm{MPa}$ pressure for the polysulfone - alkylbenzyl dimethylammonium chloride

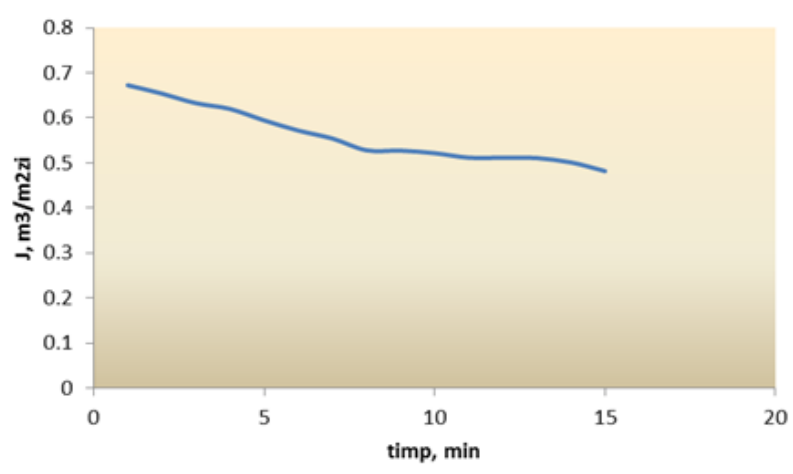

Fig. 6. Flow variation at $0.3 \mathrm{MPa}$ for the polysulfone alkylbenzyldimethylammonium chloride

the highest pressure are, from this point of view, the lowest recorded for this type of membrane. These can be compared to the results obtained for the polysulfone membrane. For the composite membrane of polysulfonealkylbenzyldimethylammonium chloride the bestrecorded value was for the pressure of $0.1 \mathrm{MPa}$.

The degree of retention for this type of membrane is graphically represented in figure 7 . Retention coefficient for the $\mathrm{E} 104$ dye solution ranged from 24.4 to $13.9 \%$ for the composite membranes made from polysulfonealkylbenzyldimethylammonium chloride using dead-end filtration. For this membrane the retention degree achieved high values for the low pressure and small values for high pressures.

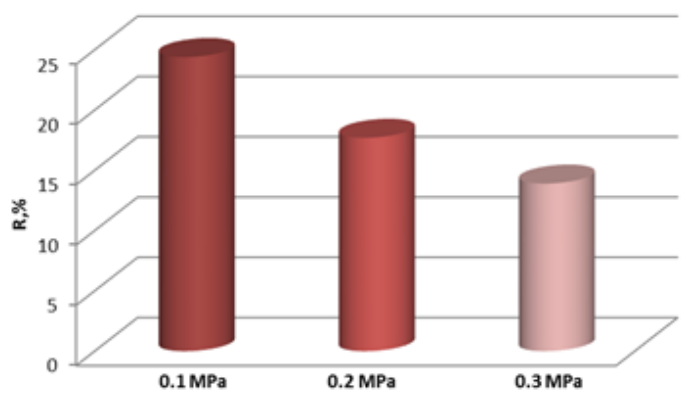

Fig. 7. The retention ratio of the dye (R) for the polysulfone alkylbenzyldimethylammonium chloride

For determining the retention coefficient, it was also done to determine the concentration of permeate and retentate solutions using spectrophotometric measurements absorbance at the wavelength of $575 \mathrm{~nm}$ (fig.7).

The results obtained also at three different pressures for the polysulfone - N-dodecylpyridinium chloride (PSUNDPCl) membranes were presented in figures 8 -14.

Working conditions: Initial solution: $\mathrm{C}_{18} \mathrm{H}_{13} \mathrm{NO}_{5 / 8113} \mathrm{~S}_{1 / 2 / 3} \mathrm{Na}_{1 / 2}$ , $10 \%$ (equivalent to $100 \mathrm{~g} / \mathrm{m}^{3}$ ) - E104; Process duration: $30 \mathrm{~min}$; Spectrophotometric measurements at the wavelength of $575 \mathrm{~nm}$; Initial temperature: $19.7^{\circ} \mathrm{C}$; Final 


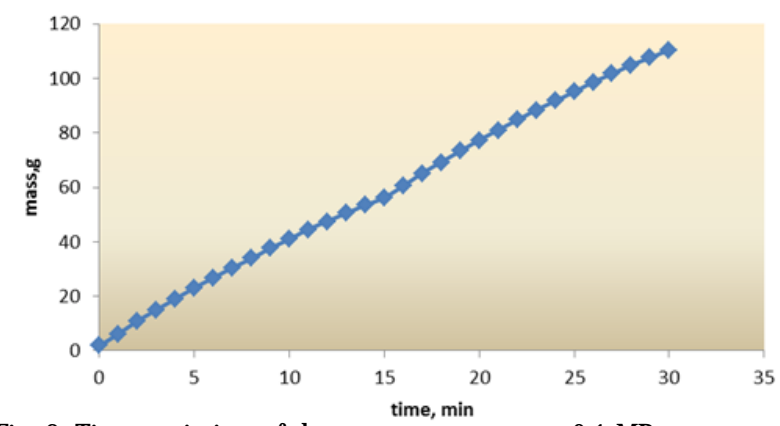

Fig. 8. Time variation of the permeate mass at $0.1 \mathrm{MPa}$ pressure for the polysulfone - N-dodecylpyridinium chloride

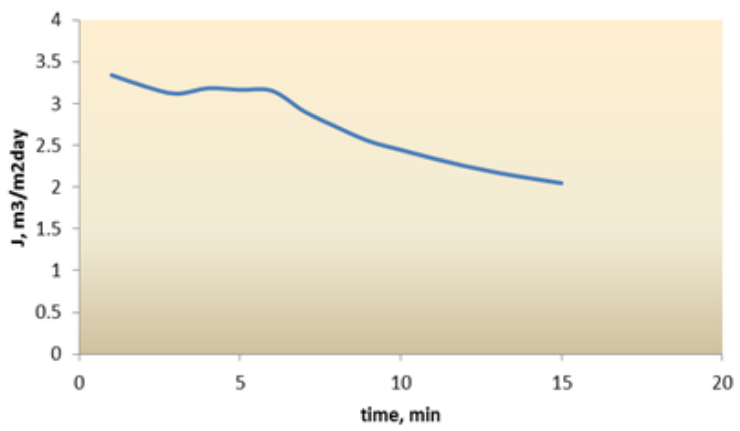

Fig. 9. Flow variation at $0.1 \mathrm{MPa}$ for the polysulfone $\mathrm{N}$-dodecylpyridinium chloride

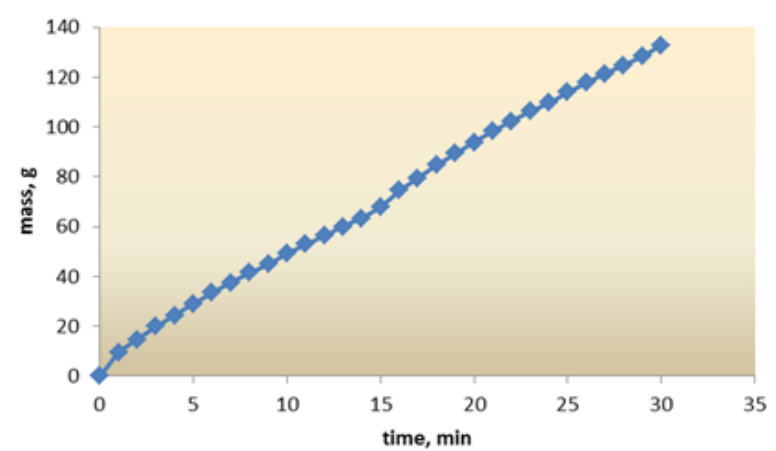

Fig. 10. Time variation of the permeate mass at $0.2 \mathrm{MPa}$ pressure for the polysulfone - $\mathrm{N}$-dodecylpyridinium chloride

temperature: $22.9^{\circ} \mathrm{C}$; Pressure: $0.1 \mathrm{MPa}$; Operation of the installation: dead-end (figs. 8 and 9).

For this membrane, the best flows at the operating pressure of $0.1 \mathrm{MPa}$ were obtained, ranging from 2.0481 to $3.3422 \mathrm{~m}^{3} / \mathrm{m}^{2}$ day.

Working conditions: Initial solution: $\mathrm{C}_{18} \mathrm{H}_{13} \mathrm{NO}_{5 / 111} \mathrm{~S}_{123}$ $\mathrm{Na}_{1 / 23}, 10 \%$ (equivalent to $100 \mathrm{~g} / \mathrm{m}^{3}$ ) - E104; Process duration: 30 minutes; Spectrophotometric measurements at the wavelength of $575 \mathrm{~nm}$; Initial temperature: $20.2^{\circ} \mathrm{C}$; Final temperature: $22.5^{\circ} \mathrm{C}$; Pressure: $0.2 \mathrm{MPa}$; Operation of the installation: dead-end (figs. 10 and 11).

For the same analyzed solution, at a pressure of $0.2 \mathrm{MPa}$, the flow value is between 1.3231 and $2.2048 \mathrm{~m}^{3} / \mathrm{m}^{2}$ day, considerably lower values than those obtained under the same conditions at a pressure of $0.1 \mathrm{MPa}$. Although the recorded values were lower than for the $0.1 \mathrm{MPa}$ pressure, the trend was constant and maintained

Working conditions: Initial solution: $\mathrm{C}_{1} \mathrm{H}_{1} \mathrm{NO}_{5} \mathrm{~S}_{1}$ $\mathrm{Na}_{1 / 23}, 10 \%$ (equivalent to $100 \mathrm{~g} / \mathrm{m}^{3}$ ) - E104; Process duration: 30 minutes; Spectrophotometric measurements at the wavelength of $575 \mathrm{~nm}$; Initial temperature: $20.6^{\circ} \mathrm{C}$; Final temperature: $23.2^{\circ} \mathrm{C}$; Pressure: $0.3 \mathrm{MPa}$; Operation of the installation: dead-end (figs. 12 and 13).

The flow value ranges from 1.2056 to $2.1192 \mathrm{~m}^{3} / \mathrm{m}^{2}$ day, thus maintaining a downward trend. Flow values for the highest pressure are, from this point of view, the lowest

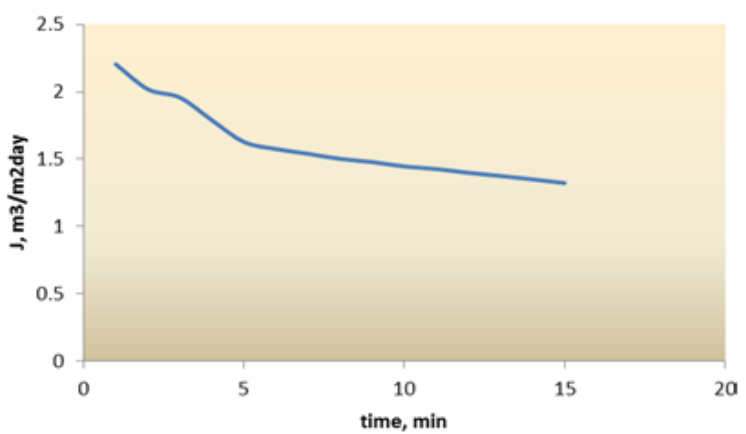

Fig. 11. Flow variation at $0.2 \mathrm{MPa}$ for the polysulfone $\mathrm{N}$-dodecylpyridinium chloride

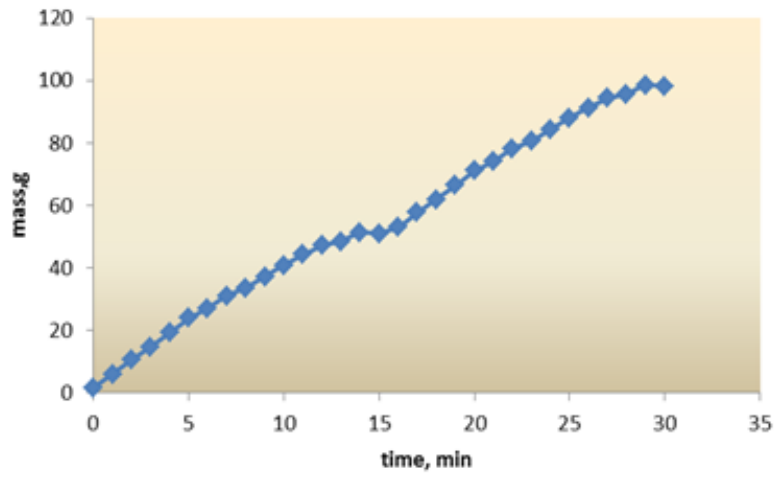

Fig. 12. Time variation of the permeate mass at $0.3 \mathrm{MPa}$ pressure for the polysulfone - N-dodecylpyridinium chloride

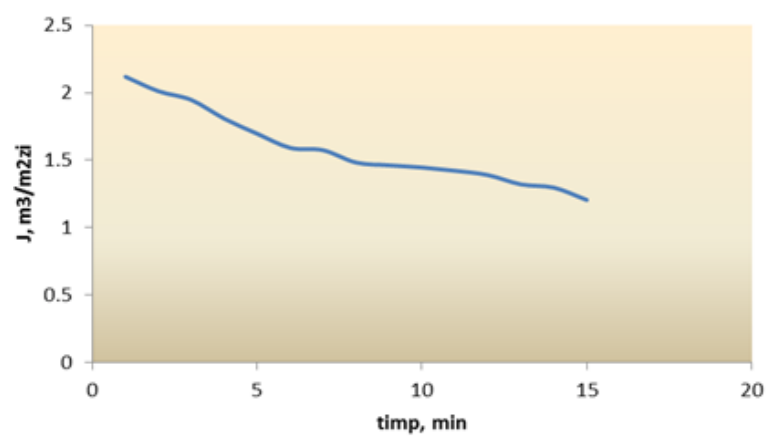

Fig. 13. Flow variation at $0.3 \mathrm{MPa}$ for the polysulfone - N-dodecylpyridinium chloride

recorded for this type of membrane. These results are similar to those obtained for the polysulfonealkylbenzyldimethylammonium chloride membranes and can also be compared with the results obtained for the polysulfone membrane (as order of magnitude). For the polysulfone-N-dodecylpyridinium chloride membrane the best recorded value was for the pressure of $0.1 \mathrm{Mpa}$.

The degree of retention for this type of membrane is graphically represented below and can be compared with the results obtained before (fig. 14).

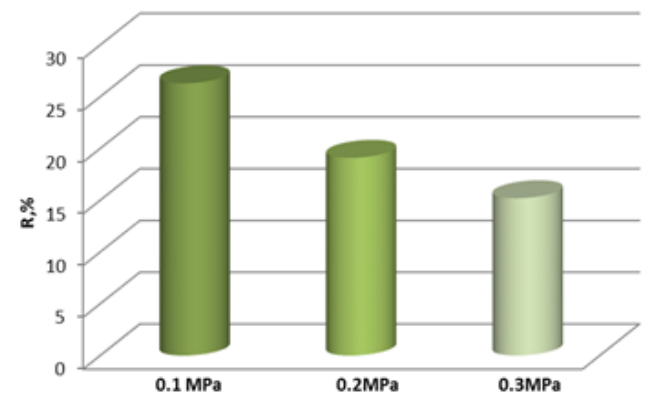

Fig. 14. The retention ratio of the dye (R) for the polysulfone - Ndodecylpyridinium chloride 
The retention coefficient for the $\mathrm{E} 104$ dye solution ranged from 266.3 to $15.2 \%$ for $\mathrm{N}$-dodecylpyridiniumpolysulfone-based composite membranes using dead-end filtration. the degree of retention is completely different, resulting in high values for low pressures and small values for high pressures. The results are similar to those obtained for the alkylbenzyl dimethylammonium chloride polysulfone membrane. Itcan be mentioned that retention was better for this type of membrane.

For determining the retention coefficient, it was also done to determine the concentration of permeate and retentate solutions using spectrophotometric measurements absorbance at the wavelength of $575 \mathrm{~nm}$.

\section{Conclusions}

The membranes undergoing the experimental study showed good mechanical and chemical resistance. The flows presented comparative values with literature data. The best flows were obtained for the highest pressures used in the plant. Regarding retention, it was observed that the The ultrafiltration efficiency of the solution containing dye is influenced by the type of membrane used, but also by the type of surfactant used in preparation. The transport propertyes of the composite polysulfone membranes are influenced by the content of the treated solutions. Although in terms of flux the resulults are related, in terms of retention the best results were recorded for the polysulfone $\mathrm{N}$-dodecylpyridinium chloride membranes compared to the polysulfone - alkylbenzyl dimethylammonium chloride membranes, most probably function of to its structure.

Acknowledgements : The work has been funded by UEFISCDI PN-IIPT-PCCA-2013-4-0742 Projectfor PhD students support and the Sectoral Operational Programme Human Resources Development 2007-2013 of the Ministry of European Funds through the Financial Agreement POSDRU/159/1.5/S/134398.

\section{References}

1.SUN, O., YANG, L., Water Research, 7, 2003, p. 315

2.AHMAD, A.L., PUASA, S.W., ZULKALI, M.M.D., Desalination, 191, 2006, p. 15

3.ARCHER, A.C., MENDES, A.M., BOAVENTURA, R.A.R.,Environ. Sci. Technol., 33,1999, p. 2758

4.MAJEWSKA-NOWAK, K., Environment Protection Engineering, 31, 2005, p. 229

5.MAJEWSKA-NOWAK, K., Environment Protection Engineering, 32, 2006, p.78

6.JUNGERMAN, E., - Cationic Surfactants, Marcel Dekker, New York, 1970;
7.RUBINGH, N., HOLLAND, P. M., (ed.) - Cationic Surfactants - Physical Chemistry, Marcel Dekker, New York, 1991;

8.Van der BRUGGEN B., DAEMS, B., WILMS, D., VANDECASTEELE, C., Separation and Purification Technology, 22-23, 2001, p. 519

9.BAEURLE, S.A., KROENER, J., J ournal of Mathematical Chemistry, 36, 2004, p. 409

10.MUNIR, A., Dead End Membrane Filtration, ENE 806, Laboratory Feasibility Studies in Environmental Engineering, Springer, 2006

11.NECHIFOR, G., ALBU, B.G., RATA, D., POPESCU, G., Rev. Chim. (Bucharest), 47, no. 3, 1996, p. 260

12.POPESCU, G., NECHIFOR, G., ALBU, B., LUCA, N., Rev. Roum. Chim. (Bucharest), 34, no. 2, 1989, p. 577

13.NECHIFOR, G., LUCA, N., POPESCU, G., NECHIFOR, M., Rev. Roum. Chim.(Bucharest), 34, no. 11-12, 1989, p. 2047

14.KIMA, C.K., KIMB, S.S., LIMC, J.C., KIMD, J.J., J. Membr.Sci., 147, 1998, p.13

15.BATRINESCU, G., CONSTANTIN, M.A., CUCIUREANU, A., NECHIFOR, G., Polymer Engineering and Science, 54, no. 7, 2014, p. 1640, DOI:10.1002/ pen.23707

16.CUCIUREANU, A., BATRINESCU, G., BADEA, N.N., RADU, D.A., NECHIFOR, G., Mat. Plast., 47, no. 4, 2010, p. 416

17.NECHIFOR, G., VOICU, S.I., NECHIFOR, A.C., GAREA, S., Desalination, 241, no. 1-3, 2009, p. 342

18.VOICU, S.I., STANCIU, N.D., NECHIFOR, A.C., VAIREANU, D.I., NECHIFOR, G., Romanian J ournal of Information Science and Technology, 12, no.3, 2009, p. 410

19.VOICU, S.I., ALDEA, F., NECHIFOR, A.C., Rev. Chim. (Bucharest), 61, no. 9, 2010, p. 817

20.RIKABI, A.A.K.K., CUCIUREANU, A., CHELU, M., MIRON, A.R., ORBECI, C., POPA, A.G., CRACIUN, M.E., Rev. Chim. (Bucharest), 66, no. 8, 2015, p. 1093

21.RIKABI, A.A.K.K., NECHIFOR, A.C., MOHAMMED, T. J., OPREA, O., MIRON, A.R., SEGARCEANU, M., VAIREANU, D.I., Rev. Chim. (Bucharest), 67, no. 8, 2016, p. 1489

22.RIKABI, A.A.K.K., BALABAN (CHELU), M., HARABOR, I., ALBU, P.C., SEGARCEANU, M., NECHIFOR, G., Rev. Chim. (Bucharest), 67, no. 9,2016, p. 1658

23.AL ANI, H.N.A., CIMBRU, A.M., TRISCA-RUSU, C., TANCZOS, S.K.., CUCIUREANU, A., NECHIFOR, A.C., Rev. Chim. (Bucharest), 68, no. 2, 2017, p. 203

24.AL ANI, H.N.A., CIMBRU, A.M., TANCZOS, S.K.., DIN, I.S., CUCIUREANU, A., NAFLIU, I.M., NECHIFOR, G., Rev. Chim. (Bucharest), 68, no. 3, 2017, p. 427

25.POPA, G.A., POPA (ENACHE), D. F., SLAVE(CLE) ), D.D., DIN, I. S., MIREA, C.M., CIOCANEA, A., Rev. Chim. (Bucharest), 68, no.1, 2017, p. 6

$\overline{\text { Manuscript received: } 17.07 .2017}$ 